DOI: 10.22616/REEP.2019.022

\title{
The Development of Professional English Language Competence in Business Administration Studies
}

\author{
Tatjana Sinkus Mg. philol. \\ Latvia University of Life Sciences and Technologies, Latvia \\ tshinkus@yahoo.com
}

\begin{abstract}
Competence-based education is a perennial goal of higher education caused by economic, political, social and innovative processes which appeared together with the global market economy. This article focuses on the development of professional English language competence in the professional English course in business administration studies in higher education institutions. The aim of the study was to define the term 'professional English language competence for entrepreneurs', select and substantiate its componential contents and develop a model for the development of professional English language competence for entrepreneurs. As a result of the theoretical study it was possible to determine the following components of professional English language competence: transversal competences (comprising critical thinking, collaboration, creativity, innovative thinking and life-long learning competences), business-related competences (comprising business management and personal management competences) and foreign language-related competences (comprising linguistic, interpersonal, strategic and pragmatic competences). The model for the development of student professional English language competence is presented in the article. The created model can be used for professional English language teaching in business administration studies as it observes specific features of entrepreneurship.
\end{abstract}

Keywords: university education, professional English, professional English language competence.

\section{Introduction}

Complex demands of rapidly changing modern world challenge a higher education institution graduate to surpass the basic reproduction of theoretical knowledge. The contemporary potential professional should develop as a mature individual possessing numerous competences in order to deal with various sophisticated mental tasks at the workplace and be capable of self-realisation.

According to the OECD research (OECD, 2005, 3), nowadays educational institutions should prepare students for "more rapid economic and social change than ever before, for jobs that have not yet been created, to use technologies that have not yet been invented, and to solve social problems that we do not yet know will arise.' Apart from academic knowledge, and skills there is a number of competences which the higher school graduate need to acquire in order to function productively in society and the workplace.

The concept of ' $21^{\text {st }}$ century competences' has been increasing in attention in Europe in the recent years. The issue of developing and preparing students with $21^{\text {st }}$ century competencies that will enable them to face complex challenges now and in the future is immensely popular and usually debated by innovative educators and reformers. These competences - knowledge, skills, and features that help youth reach their full potential - are supplementary to the significant basic skills of literacy, mathematics, and factual knowledge of other subjects.

Assessing student competence development level in higher education studies B. Briede and L. Peks (2017, 708) use the following indicators: ability to use knowledge, skills and competence in new situations in studies; ability to think critically, systemically and express an opinion; ability to analyse, synthesise and assess information; ability to take decisions and judge on one's own behaviour independently; ability to cooperate with others.

The necessity to update educational systems and keep pace with changing times are connected also to students expectations who are demanding an educational system that is modernized and more connected and relevant to their everyday lives, as well as changes in the labour market and innovative, interconnected, global, rapidly transforming, technology-driven economy that requires competences suited to dynamic economic and social development. 
The students of business administration studying the professional English language in a higher education institution require a course that is relevant to their future work and that would enable them to accomplish job duties and responsibilities and achieve professional goals in communication with foreign colleagues and business partners. Thus, the aim of the study was to define the term 'professional English language competence for entrepreneurs', select and substantiate its componential contents and develop a model for the development of professional English language competence for entrepreneurs.

\section{Methodology}

In scientific literature the concept of competence is described as a dynamic combination of knowledge, understanding and abilities (Gonzalez, Wahenaar, 2008); as an 'ability to successfully meet complex demands in a particular context through the mobilisation of psychosocial prerequisites (including cognitive and non-cognitive aspects) and as the internal mental structures in the sense of abilities, dispositions or resources embedded in the individual in interaction with a specific real world task or demand' (Rychen, Salganik, 2001, 44); as 'combinations of those cognitive, motivational, moral, and social skills available to a person that underlie the successful mastery through appropriate understanding and actions of a range of demands, tasks, problems, and goals' (Weinert, 2001, 2433); as a result of a certain level of education; it can be defined by professional education, experience, student's individual abilities, his 'motivated pursuit of continuous self-education, self-development, creative and responsible attitude to the activity (Gershunsky, 1998, 608); as 'more than just the acquisition of knowledge and skills; it involves the mobilisation of knowledge, skills, attitudes and values to meet complex demands' (OECD, 2018, 5).

Within the process of the theoretical analysis of findings on competence-oriented approach in education, competence definition and classification, the concepts transversal competences, business-related competences and foreign language-related competences were examined. Following is the discussion of these competences.

\section{Results and Discussion}

Transversal competences (comprising critical thinking, collaboration, creativity, innovative thinking and life-long learning)

The research in 21 st century competencies is mostly associated with growth in the importance of so-called transversal competences as they are regarded as key indicators for competitiveness, employability and success in job performance. Transversal competences are trans-disciplinary and multifunctional. They extend over numerous aspects of human life and comprise knowledge of various academic disciplines.

European Commission consider transversal competences as a key outcome of higher education which will help people deal with today's varied and unpredictable career paths and will help contribute to employability of young people in particular, as well as supporting creation of new business (Employment, Social Affairs..., 2014).

N. Tsankov $(2017,129)$ states that transversal competences "are basic and guarantee that individuals can handle their future roles". The researcher emphasizes that the development of transversal competences is one of the most important tasks of education as it is "an opportunity to orient the goals of education towards the personality and make it relevant in terms of the individuality of learners are an expected educational outcome and a key factor for the cultivation of all other specific competences".

There is no unified conceptual framework describing transversal competences, each initiative and every author introduces complementary ideas to the concept of the 21 st century competences. However, the majority of the researches emphasize the necessity to develop such transversal competences as: critical thinking, collaboration, creativity, innovative thinking and life-long learning. These transversal competences are regarded as very significant not only for the students of business administration but for every higher school graduate in the 21 st century regardless of the program they study.

Critical thinking in the 21 st century is described by M. Fullan $(2013,23)$ as the 'ability to design and manage projects, solve problems, and make effective decisions using a variety of tools and resources. It is the ability to think clearly, independently and rationally, and it implies engagement in reflection'. 
Collaboration is a vital competence that a person needs to develop in the $21^{\text {st }}$ century as it is necessary for labour market and most jobs nowadays require individuals to work in teams where each team member contributes to a finished product or completed service. Partnership for 21st Century Skills state that mastering collaboration skills requires the ability to work effectively with diverse teams. It also requires the 'ability to be helpful and make necessary compromises to accomplish a common goal' as well as to 'assume shared responsibility for collaborative work' (Partnership for 21 st..., 2009, 4)

According to Partnership for $21^{\text {st }}$ Century Skills framework, creativity and innovation are the core competences of the $21^{\text {st }}$ century, as they involve 'the ability to turn ideas into action to meet the needs of a community. The capacity to enhance concepts, ideas, or products to contribute new-to-the-world solutions to complex economic, social, and environmental problems involves leadership, taking risks, independent/unconventional thinking and experimenting with new strategies, techniques, or perspectives, through inquiry research. Entrepreneurial mindsets and skills involve a focus on building and scaling an idea sustainably'. The research underlies the importance of thinking creatively, working creatively with others and implementing innovations (Partnership for 21 st..., 2009, 5).

The importance of lifelong learning has also become a popular issue recently. Nowadays, it is required to keep current and constantly upgrade and increase knowledge and skills throughout the lifespan, engagement in lifelong learning is considered as critical to success.

According to M. Laal and P. Salamati $(2012,399)$, 'In the 21st century, we all need to be lifelong learners. Our world is changing around us in such a frantic pace that if we do not continue to grow and develop; we will soon be left behind. We need to continually keep our skills sharp and up to date so that we have an edge in all we do.'

For the last few years the development of the entrepreneurial capacity of European citizens and organisations has been one of the key policies aims for the European Union. European Commission highlights the significance of entrepreneurial competence development for society and economics as it contributes to job creation and economic growth, is essential for competitiveness and opens up individual personal opportunities (Green Paper..., 2003, 6-7).

To sum up this subsection, transversal competences: critical thinking, collaboration, creativity and innovation, lifelong learning and entrepreneurship, each being a combination of knowledge, skills, character features and attitudes are fundamental in the 21 st century and necessary for every person, as they provide an opportunity of effective participation and self-realization in a variety of educational, professional and social contexts. They are prerequisites for well-being, adapting to a changeable and complex world and meeting the demands of today's society, being competitive in the labour market, managing profitable business and developing an enterprise.

Now, when the concept of transversal competences has been discussed, the focus of the paper shifts to the question what competences are necessary to the area of business administration specifically. In this article it is suggested that apart from possessing general transversal competences a business administration student should acquire peculiar, domain-related competences, namely business-related competences.

\section{Business-related competences (comprising business management and personal management competences)}

Business administration graduates are professionals who can combine different functional areas within enterprises (economics, administration, finance, accounting, human resources, sales and marketing, logistics and production) in private and state sectors. In the present research, it is suggested that the students of business administration should acquire business-related competences comprising of business management and personal management competences.

Business management competence is a prerequisite for success in the world of entrepreneurship. If entrepreneurs lack this competence, they may find the task of setting up and maintaining their businesses more complicated. Developing business management competence is not only providing students with theoretical and practical knowledge of the business domain, higher education should provide students with an opportunity to develop their individual conceptual abilities, skills, attitudes and behaviours that can be practically applied in current, unpredictable, ever-changing and interconnected business environment. These abilities, which are a major factor in innovation, productivity and competitiveness, 
are all interdependent, and the emphasis is on critical thinking, decision taking, initiative, and communication.

Besides business management, business-related competence comprises also a personal management competence. A personal management competence of the entrepreneur is a set of knowledge, abilities, skills, character features, behaviours, and attitudes that must be mastered by the individual entrepreneur rather than being shared within a group or team. Developing the entrepreneur's personal management competence is highly important in business administration studies since entrepreneurship offers the opportunity to work according to personal goals, interests, values, and beliefs, striving toward their development and realization.

Personal management competence involves cognitive strategies needed to perform business activities and apply the gained knowledge and skills to processing information, to adapting and transforming knowledge, to constructing personal knowledge and judgments. It also assumes the ability to manage and coordinate self-growth, self-realization, personal time, various life and work circumstances, in other words, to play an active role in shaping business environment as well as personal life. If personal management competence is lacking, entrepreneurs may give up even in spite of financial success.

Now, when the content of business-related competences has been outlined, there is a need to include the foreign language-related competences' dimension, as it is important to find out what competences should be developed in the professional English course in business administration studies.

\section{Foreign language-related competences (comprising linguistic, interpersonal, strategic and pragmatic competences)}

The students enrolling business administration studies in Latvia are school leavers who passed their mandatory centralized exam in English in secondary schools and who already possess basic skills in general English. In business administration studies in the professional English course students should develop the ability to communicate in different business situations, improve interactive, discussion and negotiation skills, extend the previously acquired vocabulary, get an insight into business terminology and develop and improve the required lexis for exchanging information related to business, management, services; consolidate and extend the knowledge of relevant functional grammar structures; and develop business writing skills.

To realize these aims, the business administration student should integrate his transversal and businessrelated competences with more specific, foreign language-related competences. Therefore, foreign language-related competences serve as a supporting platform for the transversal and business-related competences with the aim to ensure successful functioning in specific intercultural professional communicative situations. In the present research, the foreign language-related competences for the entrepreneur are linguistic, interpersonal, pragmatic and strategic.

Linguistic competence, according to 'Common European Framework of Reference for Languages', (Common European Framework, 2001) includes 'lexical, phonological, syntactical knowledge and skills and other dimensions of language as system, independently of the sociolinguistic value of its variations and the pragmatic functions of its realisations.' Linguistic competence relates not only to the range and quality of knowledge, but also to cognitive organisation and the way this knowledge is stored, as well as its accessibility.

In the area of foreign language learning, as R.A. Fisher (1984) states, 'linguistic competence may be thought of as the learner's knowledge of the structures and vocabulary of the foreign language and his ability to produce and comprehend well-formed sentences'. The student who possesses linguistic competence is equipped with lexical and grammatical knowledge and rules which can be used in communication.

Lexical and grammatical competences are interdependent underlying components of linguistic competence. In this research, linguistic competence for entrepreneurs is defined as the ability to use both sub-competences, lexical and grammatical, in order to recognize and produce words and grammatical structures to use them effectively in a certain professional communicative situation.

Apart from linguistic competence, the students of business administration have to acquire interpersonal competence as the central factor in the business activity is interpersonal communication. OECD present 
interpersonal competence as the ability to relate well to others, empathy and effective management of emotions. This includes 1) the ability to present ideas and listen to those of others, and an understanding of the dynamics of debate and of following an agenda, 2) the ability to construct tactical or sustainable alliances, 3) the ability to negotiate, and 4) the capacity to make decisions that allow for different shades of opinion (OECD, 2005).

In this article, interpersonal competence is defined as a personal set of knowledge, behaviours, skills and abilities of the business administration student necessary to be able to interact and get along well with others in business environment, and function constructively in groups; it is an effective use of communicative tools and personal resources, native and foreign language, new technologies as well as knowledge, strategies, laws, information, according to requirements of the modern business world in order to solve professional tasks.

The learners of high level of linguistic and interpersonal competence may not necessarily possess equivalent level of pragmatic competence development. As D. Mindt (1996) points out 'Learners who leave their school surroundings, very often find it hard to adapt to the English used by native speakers. Learners who communicate with native speakers constantly have to reshape their linguistic behaviour in those areas of the language which were not taught properly.'

According to P. Garcia (2004), when communicating in the foreign language, more than lexical and grammatical knowledge is necessary; the speakers must be aware about the way the language is used in a specific culture, the norms of that people for communication in a particular context. This is the pragmatics of a language which is the 'ability to use language appropriately according to the communicative situation'.

Therefore, it is also very important for the teacher to be aware of the specific context and communicative situations the students of business administration are supposed to deal with. The development of the professional English language pragmatic competence is paramount in business administration studies as this competence represents a system of rules of what is acceptable and what is not acceptable for the speaker in the language he speaks in entrepreneurial environment.

Another competence the students of the business administration have to acquire in the professional English course is strategic competence. As S. Savignon (2010) points out, misunderstandings and minor or major breakdowns in communication occur in a large variety of communicative situations and the 'effective use of coping strategies is important for communicative competence in all contexts and distinguishes highly effective communicators from those who are less so'.

In the present research strategic competence is defined as a set of knowledge and skills to solve communicative problems, to regulate verbal and non-verbal communicative actions selected for the achievement of communicative goals in business context in specific conditions. Strategic competence could help learners in situations when they are unable to express themselves and carry out their communicative intent, when they are unable to understand what has been said to them, or face problems when interpreting messages, in spite of using a wide range of vocabulary or correct grammar structures.

Strategic competence is composed of a number of different communication strategies which can be used in order to overcome breakdowns in communication, whether the problems are caused by insufficient lexical, grammatical and pragmatic competence. Thus, it is very important that the prospective entrepreneurs acquire strategic competence in business administration studies.

To sum up, linguistic, pragmatic and strategic competences are relevant to any foreign language learner, and especially to the student of business administration, a prospective entrepreneur, whose goal is the achievement of communicative goals in an intercultural business context in specific professional circumstances.

Having analysed and summarized the theoretical research on the concept 'competences of the 21 st century entrepreneur', transversal competences, business-related and foreign language-related competences, the author has defined professional English competence for entrepreneurs as follows:

Professional English language competence for entrepreneurs is an entity of interrelated sub-competences: transversal, business-related and foreign language-related competences, developed in professional 
English language course in business administration studies which empowers an entrepreneur to complete job responsibilities and achieve professional goals in order to promote business.

A set of competences based on the research in Latvia and worldwide has been selected and worked out. The author has concluded that entrepreneur's professional English competence consists of eleven competences which are grouped into three interrelated clusters a) a set of transversal competences, b) a set of business-related competences, connected to entrepreneurial professional context and c) a set of foreign language-related competencies, connected to the foreign language professional communication context. The cluster of transversal professional competences comprises critical thinking, collaboration, creativity, life-long learning and entrepreneurship. The cluster of business-related competences includes business management and personal management competences. The cluster of foreign language-related competences consists of linguistic, interpersonal, pragmatic and strategic competences.

The benefits of developing each competence for an entrepreneur are summarized below.

Critical thinking competence enables an entrepreneur to think rationally, logically, systematically, analyse issues, distinguish between facts and opinions, make independent judgement, transfer acquired knowledge into new situations in order to promote business.

Collaboration competence enables an entrepreneur to work effectively as a member of a team in order to achieve a business benefit; being active, helpful and bringing a personal contribution to the teamwork, compromising and resolving conflicts.

Creativity and innovation competence enable an entrepreneur to seek new unobvious perspectives and opportunities in business environment, come up with original ideas to improve business procedures, solve problems in an innovative, non-traditional way, and stay ahead of competitors.

Lifelong learning competence provides an entrepreneur with an opportunity of using various opportunities to learn (formal, non-formal, informal education), engage in continuous personal development to achieve self-fulfilment, life enrichment, self-confidence and promotion of business.

Entrepreneurship competence enables an entrepreneur to promote a sense of initiative, leadership skills, accountability and ability to impress and persuade people; actively contribute to society, taking responsibility for working with others and making decisions, create a business enterprise.

Business management competence provides an entrepreneur with knowledge, conceptual abilities, skills and strategies of various integrated aspects of business domain that can be practically applied in business environment in order to plan, set up, develop, manage and improve a business activity.

Personal management competence enables an entrepreneur to manage and coordinate self-growth, selfconfidence, self-awareness, self-reflection and personal time to work according to personal goals, interests, values, and beliefs, as playing an active role in promoting business.

Linguistic competence provides an entrepreneur with knowledge and ability to use the foreign language vocabulary including general and professional lexicon, as well as theoretical and practical knowledge of grammatical rules, which allows generating correct and meaningful sentences.

Interpersonal competence enables an entrepreneur to develop social skills, to be able to interact and get along well with others in business environment, and function constructively in groups.

Pragmatic competence enables an entrepreneur to use the foreign language appropriately, understanding what is acceptable and what is not acceptable in various business situations.

Strategic competence enables an entrepreneur to develop an ability to use verbal and non-verbal communication strategies to compensate for communication difficulties or limited language knowledge and achieve communicative goals in business context in specific conditions.

Having identified and summarized the major benefits that each of these eleven competences presents for an entrepreneur it is possible to define professional English language competence indicators. 


\section{Professional English language competence for entrepreneurs}

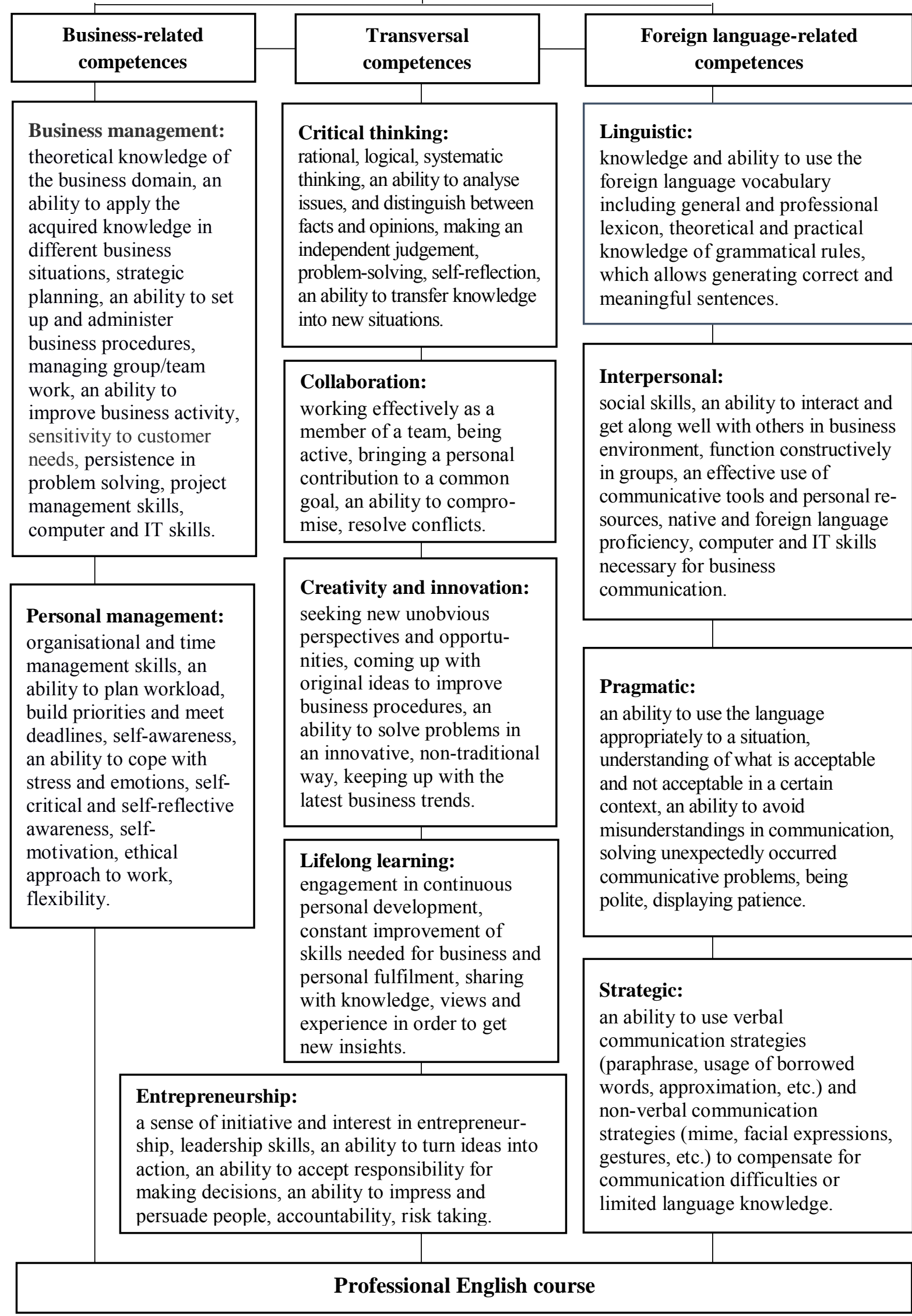

Figure 1. The model of professional English language competence for entrepreneurs in the professional English course. 
Constructing the model of professional English language competence, the author of the present research allocates a certain constituent group of abilities, knowledge and skills without which that kind of competence cannot be realized. These eleven competences coincide and interlock, however, together they form an integrated system and should be treated as a whole, the concept of professional English language competence for entrepreneurs. The model of professional English language competence for entrepreneurs developed by the author of this article is presented in Figure 1.

All the model's elements together form a systemic relationship between the process and result: in coherence with the goal and objectives, content and expected outcome of the professional English course.

\section{Conclusions}

The theoretical analysis of the concepts of transversal, business-related and foreign-language related competences is presented in this article. Professional English language competence for entrepreneurs is defined by the author in this article as an entity of interrelated sub-competences: transversal, businessrelated and foreign language-related competences, developed in the professional English language course in business administration studies which empowers an entrepreneur to complete job responsibilities and achieve professional goals in order to promote business.

The componential contents of professional English language competence for entrepreneurs are selected, substantiated and depicted in the created model. It is suggested that entrepreneur's professional English competence consists of eleven sub-competences: critical thinking, collaboration, creativity and innovation, life-long learning, entrepreneurship, business management, personal management, linguistic, interpersonal, strategic and pragmatic competences, which are grouped into three clusters: a) a set of transversal competences, b) a set of business-related competences, connected to entrepreneurial professional context and c) a set of foreign language-related competencies, connected to the foreign language professional communication context. The benefits of eleven sub-competences for the students of business administration comprising professional English language competence are summarised.

The created model of the professional English language competence for entrepreneurs (Figure 1) is applicable for the pilot use in business administration studies as it observes the specific features of entrepreneurship.

\section{Bibliography}

1. Briede B., Peks L. (2017). Competence-based Engineering Studies. In A. Aboltins (Ed.), The Proceedings of the International Scientific Conference Engineering for Rural Development, 16. Jelgava: LLU TF, 706-712. Retrieved from:

http://www.tf.1lu.lv/conference/proceedings2017/Papers/N143.pdf

2. Common European Framework of Reference for Languages: Learning, teaching, assessment. (2001). Council of Europe, Modern Languages Division. Strasbourg: Cambridge University Press, 13. Retrieved from https://rm.coe.int/16802fc1bf

3. Employment, Social Affairs and Inclusion. Developing skills. (2014). European Commission. Retrieved from: http://ec.europa.eu/social/main.jsp?langId=en\&catId=1214

4. Fisher R.A. (1984). Testing Written Communicative Competence in French. Modern Language Journal, 68 (1), 13-20.

5. Fullan M. (2013). Commentary: The New Pedagogy: Students and Teachers as Learning Partners. Learning Landscapes, 6(2), 23-29.

6. Garcia P. (2004). Pragmatic Comprehension of High and Low level Language Learners. The Electronic Journal for English as a Second Language, 8(2). Retrieved from https://files.eric.ed.gov/fulltext/EJ1068107.pdf

7. Gershunsky B. (1998). Filosofija obrazovanija dlja 21 veka (Philosophy of education for the 21 st century). Moskva: Soversenstvo. (in Russian)

8. Gonzalez J., Wahenaar R. (Eds.). (2008). Universities' Contribution to the Bologna Process. An Introduction. ( $2^{\text {nd }}$ ed.). Bilbao: Publications de la Universidad de Deusto. Retrieved from http://tuningacademy.org/wp-content/uploads/2014/02/Universities-Contribution_EN.pdf 
9. Green Paper: Entrepreneurship in Europe. (2003). Brussels: Commission of the European Communities. Retrieved from: http://ec.europa.eu/invest-inresearch/pdf/download_en/entrepreneurship_europe.pdf

10. Laal M., Salamati P. (2012). Lifelong Learning; Why Do We Need It? Procedia - Social and Behavioral Sciences, 31, 399-403.

11. Mindt D. (1996). English Corpus Linguistics and the Foreign Language Teaching Syllabus. In J. Thomas, M. Short (Eds.), Using Corpora for Language Research. Harlow: Longman, 232-247.

12. OECD. (2005). The Definition and Selection of Key Competencies. Executive Summary. Retrieved from: https://www.oecd.org/pisa/35070367.pdf

13. OECD. (2018). The Future of Education and Skills. Education 2030, 5. Retrieved from: https://www.oecd.org/education/2030/E2030\%20Position\%20Paper\%20(05.04.2018).pdf

14. Partnership for 21st Century Skills. (2009). P21 Framework Definitions. Retrieved from: https://archive.org/stream/ERIC_ED519462/ERIC_ED519462_djvu.txt

15. Rychen D., Salganik L. (2001). Defining and Selecting Key Competencies. Göttingen Germany: Hogrefe and Huber.

16. Savignon S.J. (2010). Communicative Language Teaching: Linguistic Theory and Classroom Practice. New Haven and London: Yale University Press.

17. Tsankov N. (2017). Development of Transversal Competences in School Education. International Journal of Cognitive Research in Science, Engineering and Education, 5(2), 129-144.

18. Weinert F.E. (2001). Concept of competence: A conceptual clarification. Defining and selecting key competencies. In D.S. Rychen, L. H. Salganik (Eds.), Defining and selecting key competencies. Seattle: Hogrefe and Huber Publishers, 45-65. 